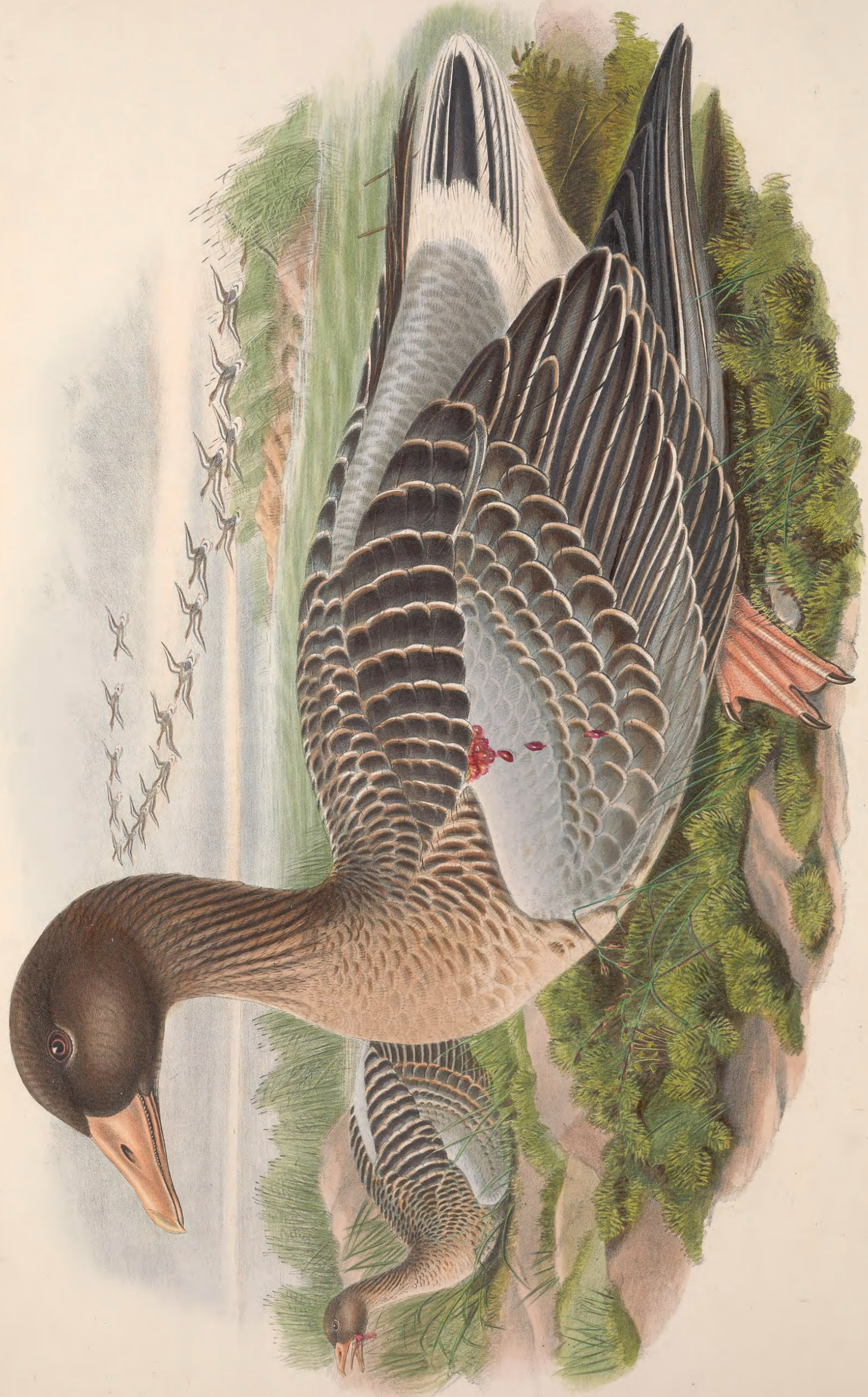

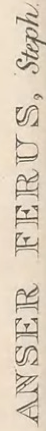




\section{ANSER FERUS.}

\section{Grey Lag Goose.}

Anas anser, Linn. Faun. Suec., p. 40.

_ferus, Gmel. edit. Linn. Syst. Nat., tom. i. p. 510.

Anser ferus, Steph. Cont. Shaw's Gen. Zool., vol. xii. p. 28.

— palustris, Flem. Hist. Brit. Anim., p. 126.

cinereus, Mey. Taschenb. Vög., tom. 3, p. 552.

sylvestris, Brehm, Vög. Deutschl.. p. 836.

vulgaris, Pall. Zoogr. Rosso-Asiat., tom. ii. p. 222.

rubrirostris, Hodgson ?, Swinh. Rev, List of Birds of China in Proc. of Zool. Soc., 1871, p. 416.

THE true habitat of the Grey Lag Goose is the temperate and northern regions of the Old World ; as yet it has not been found in any portion of the New. However general its distribution may have been in the British Islands in former times, it is at present confined to the northern part of Scotland, the Hebrides, and may be sparingly seen in Ireland. Indeed it is from this latter country that the specimens which form the subject of the accompanying illustration were received, for which $I$ am indebted to the Earl of Enniskillen, a nobleman well known for his love of science and as a liberal supporter of several of its numerous branches, especially those embracing the study of the living objects by which we are surrounded, and as an investigator of the treasures of by-gone ages. The properties of the Earl of Belmore, at Castle Cool, and of Sir Victor Brooke, at Lisnaskea, co. Fermanagh, have, I understand, from almost time immemorial, been frequented by flocks of wild geese; and it is through the kindness of the former nobleman and his steward, Mr. Hosegood, that Lord Enniskillen obtained for me the very fine pair, male and female, on the 15th of December, 1868.

Mr. R. Gray, in his 'Birds of the West of Scotland,' after speaking of the Grey Lag Goose breeding in many parts of that country, and of their nurseries on the bleak hills of the outer Hebrides, states that "it is common in North Uist, Benbecula, and South Uist, and is found occupying the breeding-stations early in May. Mr. Harvie Brown took a nest of eggs which were hard sat upon, on 2nd May, 1870; but Mr. Elwes, who visited the Long Island in 1868, saw flocks of as many as thirty together later in the season. The nest, which resembles that of a Great Black-backed Gull when found breeding on heath-clad islands, with the exception of being lined with down and feathers, is generally placed in a tuft of coarse grass, or among rank heather, and contains from four to six eggs. When the young are fully fledged, they keep together in family groups for some weeks, and are often seen shifting their quarters from one side of the island to the other."

During a visit to Lochs Shin and Merkland, as well as several parts of the Reay Forest, in the autumn of 1867, I saw Grey Lags and their broods of young in sufficient numbers to convince me that they might be considered a common bird in those parts of the British Islands; and that it was not less abundant on the numerous lakes of the west coast of Sutherland and Ross-shire will be seen from the following extract from a note transmitted to me, after my return to London, by my excellent and kind friend the Marquis of Westminster :- "Loch More, September 4. You will like to hear about the Grey Lag Geese. The forester on the shore of Loch Merkland fired into a lot of fourteen, wounding four ; they pursued them in a coble, and procured one, which we ate ; they will try to get the others."

I shall close this paper with some extracts from an amusing and, I am sure, very truthful account of one mode of shooting this bird on its native lochs, which appeared in 'Land and Water' on the 15th of October, 1870, under the title of "A Wild-Goose Chase in Sutherland":-

" The breeding-places of the Wild Goose are yearly becoming more circumscribed all over the north; and even in Sutherland, where, perhaps, they were more numerous than elsewhere, they are now confined to one or two districts, the most fertile being a chain of lakes, with islands and rushy margins, running for about eight miles across the interior of the county, from Badinloch to Gernsary. Here the Grey Lag, principally with a few of the Bean Goose and Pink-footed Goose (the latter, however, only rarely), still breed by hundreds. We are inclined to think that the different sorts of Geese do not mix or associate during the breeding-season, but, on the contrary, form separate communities until disturbed, when they take refuge on the water in one large body. They float and plume themselves here in comparative safety all day, and at night land on the grassy feeding-places, eating up and soiling the very finest pasture in such a manner that deer or sheep will scarcely approach it after them. For many a day, with the exception of a solitary boat following a flock and potting a few, none, either young or old, were killed; and some years ago it 
struck us that by collecting a number of boats and placing a good gun in each, a very exciting battue might be organized. This we have now carried out for many seasons with varying success ; but oftener than once we have bagged from fifty to sixty Geese in a day, and had in doing so an amount of hard shooting and pulling to satisfy the most ambitious.

"About the 20th of July is the proper time to meet for this sport, as then the young birds, although nearly the size of the old Geese, are not strong on the wing; indeed, after they are able to take long flights, there is little to be done in the way of shooting them.

"Imagine, then, half a dozen ' good men and true' convening at the comfortable inn of Achintoul, within six miles of the lochs, a few days beforehand, armed with all calibres, from S., with his mighty 8-bore breech-loader, down to the Major's sharp-shooting 16. Rods, reels, boots, and baskets lumber the lobby in sweet confusion; for the standing orders are that we are to fish the numerous detached lochs until a dead calm day should permit of our properly carrying out the chasse.

" The keepers on the upper lochs have driven down the Geese, and concentrated them on the lowest and largest sheet of water ; and 'Donald' reports that 'there is an awful lot of them.' So with a night-cap of hot toddy we turn in early to bed, and are cruelly roused out of glorious slumbers at 5 A.m. by heavy knuckles on the door. Up we jump, and take an anxious look at the horizon. All seems serene; and Ben Griam has thrown off his foggy mantle, showing the clear outline of his bald head against the blue skyalways an omen of settled weather. Bitters (that horrid Celtic habit, which Saxons langh at but soon so kindly fall into), followed by breakfast, are soon despatched. Guns, ammunition, and lunch have been packed in a cart, and under careful hands are jolting their way to the lochs over a track which does the double duty of a road in summer and a water-course in winter !

" Every glass is out to scan the water, and Geese are counted by the hundred; so, making sure that the shore and outlets are all properly guarded, we embark, a gun in each boat, and form line, with a proper distance intervening, and the lightest boats on the flanks and a little in advance, so as to head the Geese should they attempt to break. Thus we pull gently down the loch until we get so near the Geese that the boats can safely close upon them. The birds get very restless, and head up and down in long strings; but the flanking boats stop them, and we are within range. The battue is soon opened by some of the old birds, after a premonitory screech to show they have made up their minds, taking wing across the line of boats. Bang! bang! bang! and down comes an old gander, with a flop sufficient to sink the little dingy underneath; and 'first blood to the oily gunner!' comes cheerily across the water ; every boat opens fire, fast and furious, and the plucky owner of No. 8 bore, careless of recoil, cuts down lanes of Geese, and deafens his assistant loader, who after each discharge feels if his head is on and puts in a fresh cartridge. All order is now at an end ; the birds separate into small lots over the loch, and each boat cuts out an independent course."

"Note of two Irish Grey Lag Geese received from Lord Enniskillen, December 15th, 1868._One, a male, weighed ten pounds; the other, a female, seven pounds and a half. The male had the head and neck light chocolate-brown; back of the neck and back chocolate-brown, each feather margined at the tip with brownish grey; lower part of the back grey; scapularies very dark chocolate-brown, each feather narrowly edged with greyish white; shoulders, lesser wing-coverts and those of the greater coverts nearest the spurious wing, and the spurious wing itself light pure grey, each feather margined with still paler grey; three upper rows of the greater wing-coverts brown, tipped with greyish white, the lower and largest row conspicuously margined anteriorly and at the tip with greyish white; primaries and secondaries dark chocolate, with white shafts and the first four washed with grey; upper tail-coverts white, forming a zone ; external tail-feathers white, the central ones dark chocolate in the middle, the rest white; abdomen pale brownish white, with here and there small patches of black at the extremities of the feathers; vent and under tail-coverts white ; bill very deeply tinged with pink towards the tip, which is defended with a large greyish white nail; irides hazel, surrounded with a thick pink lash; feet light pinkish flesh-colour.

"The female resembles the male in colour, but is destitute of the black markings on the chest, and the grey of the rump is not so pure ; she is also conspicuously less in size."

Mr. Dresser found the Grey Lag Goose breeding all along the shores of the Gulf of Bothnia up to Tornea, and procured the eggs at the end of May. "In some of the northern towns the peasant women make a trade of catching the young birds and selling them in the market at prices varying from 20 kopecks upwards. They are easily reared and quite take the place of tame geese in some towns." He asked "one old woman how she obtained them; and she replied, by watching the time the old geese leave the nest in the evening and proceed to the water (as they always have their nests far from the shores); and by keeping in the vicinity every evening during the hatching-season, she almost invariably met the old birds leading the young to the water, and had no difficulty in catching the latter."

The principal figure in the accompanying Plate is a male, about two thirds the natural size. 


\section{$2 \mathrm{BHL}$ Biodiversity Heritage Library}

Gould, John. 1873. "Grey Lag Goose, Anser ferus [PI. 1]." The birds of Great Britain 5, -. https://doi.org/10.5962/p.324045.

View This Item Online: https://www.biodiversitylibrary.org/item/222497

DOI: https://doi.org/10.5962/p.324045

Permalink: https://www.biodiversitylibrary.org/partpdf/324045

\section{Holding Institution}

Smithsonian Libraries

\section{Sponsored by}

Biodiversity Heritage Library

\section{Copyright \& Reuse}

Copyright Status: Public domain. The BHL considers that this work is no longer under copyright protection.

This document was created from content at the Biodiversity Heritage Library, the world's largest open access digital library for biodiversity literature and archives. Visit BHL at https://www.biodiversitylibrary.org. 